Acta Universitatis Wratislaviensis No 3836

Anglica Wratislaviensia LVI, Wrocław 2018

DOI: $10.19195 / 0301-7966.56 .1$

\author{
Victoria O. Adeniyi \\ ORCID: 0000-0002-9639-0132 \\ Obafemi Awolowo University, Ile-Ife \\ vicadeniyi2k4@yahoo.com
}

\title{
Proletarian Philosophy in Selected Plays by Ola Rotimi
}

\begin{abstract}
The early plays of Ola Rotimi are literary works in which Rotimi places an emphasis on the position of the gods in man's life. They are plays in which the concept of tragedy is portrayed through the eyes of noble people. They are plays in which Rotimi places an emphasis on the nobility of birth of the protagonists. His later plays, however, put an emphasis on the proletariat. This article examines the Marxist aesthetics and ideology in Ola Rotimi's If: A Tragedy of the Ruled (1983) and Hopes of the Living Dead (1988). It reflects on Rotimi's ideological departure into revolutionary drama in his later plays compared to such earlier plays as The Gods Are Not To Blame (1979), Kurunmi (1971) and Ovonranwem Nogbaisi (1974).

The study shows that Rotimi stresses the importance of the proletariat in society as reflected in If: A Tragedy of the Ruled (1983) and Hopes of the Living Dead (1988). The paper argues that Rotimi's acceptance of a new vision of commitment as revealed in the plays is an act of intellectual decolonisation. The paper concludes that Rotimi wrote these particular plays with the conscious aim of not only representing society as it is, but also with the aim of presenting society as it ought to be.
\end{abstract}

Keywords: proletariat, Marxism, capitalism, solidarity and revolution

\section{Introduction}

Artistic works are usually based on ideological, socio-political and economic ideas and writers of such artistic works strive to articulate their convictions and aesthetic ideas for the purposes of both entertainment and education (pedagogy). These views are articulated by Mao Tse-Tung when he posits that:

...All literature and art belong to definite classes and are geared to definite political lines. There is in fact no such thing as art for art's sake, art that stands above classes or art that is detached from or independent of policies. (Tse-Tung 1967: 25) 
This is so because drama and theatre as art forms are always situated within the ideological and political worldview of the artists who create them. The artists themselves belong to one class or another and protect its values.

The concern of this paper, therefore, is to examine Ola Rotimi's If: A Tragedy of the Ruled (1983) ${ }^{1}$ and Hopes of the Living Dead (1988) ${ }^{2}$ from a dialectical materialist perspective. By this we mean that the two chosen plays are analysed and interpreted from an ideologically motivated point of view. Dialectics conceives of reality as constantly changing. The choice of these two plays is based on the fact that they are the later dramas in which Ola Rotimi breaks new ground by making a radical departure from his earlier "bourgeois" plays. His early works, The Gods Are Not To Blame (1979) ${ }^{3}$, Kurunmi $(1971)^{4}$ and Ovonramwen Nogbaisi (1974) have been criticised as:

Lacking in clear social vision, steeped in myths, poetic meta-physical preoccupation and having little or no relevance to the immediate and mundane needs of their contemporary society. (Jeyifo 1984: 4)

Rotimi's early plays seem to be "Aristotelian" in their presentation of the concepts of tragedy, tradition and culture. In them, he implements the Aristotelian concept of heroism, i.e. that of the ruling class, thereby identifying himself with that class. They are plays in which reality is portrayed as static and fixed. Thus, Ola Rotimi maintains and eulogises the status quo in them. This submission is buttressed by critics who see Rotimi as a playwright of the ruling class, using Kurunmi as a model and a paradigm of his early plays. Saddiq Balewa puts it more succinctly when he writes:

Kurunmi imitates reality but that imitation occurs through the viewpoint of the ruling class.

As such, Kurunmi is a drama of the ruling class and the playwright is a dramatist of that class.

(Balewa 1982: 3)

In his early plays, Rotimi enthrones the aristocratic class over the proletariat, thereby taking sides with the oppressors against the oppressed. However, his later works, including If: A Tragedy of the Ruled and Hopes of the Living Dead, put him on the same ideological pedestal as Femi Osofisan, Bode Sowande and Kole Omotoso, whose plays also articulate a dialectical perspective of art and society.

Rotimi's dramas of new vistas belong to the era of neo-colonialism, a period when Africans are angry at and dissatisfied with the way African leaders are denying their fellow Africans their rights. In them, Rotimi identifies with the marginalised and exploited majority in the society. He puts an emphasis on the African hoi polloi, the ordinary people, who have been socially displaced and who in turn

\footnotetext{
1 If: A Tragedy of the Ruled, 1983. All page references are to this edition.

2 Hopes of the Living Dead, 1988. All page references are to this edition.

3 The Gods Are Not To Blame, 1979.

4 Kurunmi, 1971.

5 Ovonramwen Nogbaisi, 1974.
} 
fight for their position in the society. The objectives of a proletarian philosophy are clearly formulated by Obafemi:

The internal dynamics, content and significance of art must be such that it should help the ordinary people to push history forward through clarity, passion, identification with, and intervention in, the objective lives and living conditions of the majority of a given people. (Obafemi 1988: 46)

If: A Tragedy of the Ruled and Hopes of the Living Dead are a good testament ${ }^{6}$ to drama of conscientisation ${ }^{7}$, that is, drama that awakens the consciousness of people to the social reality presented in it and makes people clamour for change. To this, Niyi Osundare replies that:

In the struggle for social justice, inaction on the side of the oppressed is a suicidal sin, for inaction is the harbinger of lethargy, the lethargy aids the perpetuation of oppression and suffering. (Osundare 1980: 150)

In If: A Tragedy of the Ruled and Hopes of the Living Dead, Rotimi stresses the importance of the common people. In these plays, he seems to be of the view that socio-historical events which generate conflicts in society are caused by man and not by any supernatural power. In other words, the plays reveal that the problems in society are created by men, and not given or predestined, and as such, these problems should be challenged and solved by men. The plays maintain that nothing is fixed or predestined in a society, and so a status quo that is retrogressive should be challenged and changed.

Although Rotimi's works cut across the major genres of drama - tragedy and comedy - one can observe that he has a preference for tragedy. Both If: A Tragedy of the Ruled and Hopes of the Living Dead belong to the tragic genre. In an interview with Rotimi, Adelugba makes the following observation:

...You are trying to create a new form... In other words, I don't see your works as conforming to traditional Western definitions of tragedy solely... I think they've taken something from the Western definitions... (Adelugba 1984: 41)

Rotimi's response to Adelugba shows that he is sensitive to the temperament of the Nigerian audience when he writes. According to him:

There are certain things the Western will consider in tragedy, which will be regarded here as ridiculous... (Adelugba 1984: 41)

He sees the temperament of the Nigerian audience as being different from that of a Western audience, and gives the example of a lady who loses her child and yet laughs it away, saying "Eh-en". ${ }^{8} \mathrm{He}$ argues that some critics may refer to this as

6 The term, as used here, refers to the two chosen plays under consideration as being tangible proof of what drama of conscientisation is.

7 The term conscientisation refers to the process of making the oppressed and victimised become aware of their situation in the society, leading them to demand a change in the situation.

8 This is a Nigerian style of laughing at an unpleasant situation. 
satirical laughter, but it is "a way of laughing at sorrows or laughing away sorrows which could appear silly in the Western world or to the Westerner" (Adelugba 1984: 41). This reveals that the Nigerian audience often laughs at situations that some other people would treat as serious.

He sees the Nigerian audience as one that it is difficult to persuade into a suspension of disbelief when they are watching a true-to-life play on stage. Realizing this, Rotimi explains:

...When I approach my tragedy, I also have at the back of my mind the ... conviction ... that the Nigerian audience, unlike the Western audience, makes a clear distinction between reality and illusion... whereas the Western audience might be prone to being goaded into assuming a situation on stage as real, the Nigerian audience finds it difficult... (Adelugba 1984: 42)

His solution to the above problem is to give the Nigerian audience a feeling that what they are watching is not really true-to-life, but that it could happen. This could be done by getting them emotionally and psychologically involved in the drama and later letting them become conscious of the fact that they are still in the theatre watching a play. This explains why Rotimi suffuses his tragedy with comic relief in his attempt to reflect the philosophical stance of the Yoruba. He makes use of music and dance as well as simple vocabulary coupled with spectacle to sustain the interest of the audience from the beginning to the end of the play. The focus of this study is on the ideological as well as the functional aesthetic relevance of struggling for an ever more democratic society. Following this preamble, we shall now move to an analysis of the plays under consideration.

\section{If: A Tragedy of the Ruled}

If: A Tragedy of the Ruled involves the theme of solidarity through a group of tenants who differ in terms of ethnicity and origin, but are living in a multi-tenanted building. The tenants represent a cross-section of Nigeria as a nation, with Akpan, Chinwe and Dokunbo coming from the East, Mallam Garuba Kazaure and Dr. Hamidu alias Che Guevara from the North, and Banji and Betty from the West and Mid-west respectively. The Landlord serves each of the tenants a notice to quit with the aim of intimidating them into voting for him as a senator. However, the tenants refuse to be divided. Though different in terms of social status, religion, language and gender, they forget their differences and become united under the positive leadership of Papa to fight their common enemy, the Landlord:

...We must let the Landlord know that we all here are one. If because we refuse to take oaths to vote for him in the coming election, this now is his way of punishing us, fair enough. But, let him punish all of us. No exceptions. I see divide and rule tactics at work here, and we must resist them at all costs. (13) 
Thus, the tenants are determined to vote out the party of the Landlord instead. As Papa puts it:

But we must bide our time. Everything really depends on our votes... any vote cast for a position tomorrow on the basis of sheer fatherhood by birth; or of brotherhood by clan or sisterhood by religion is your doom and my doom. (14-15)

Rotimi brings to the fore the only weapon which the oppressed masses could use to release themselves from the long-standing grip of exploitation. This weapon is, however, dependent on a big If. In other words,

If the masses, the oppressed masses, again for a change, will use their votes as tools for their own freedom. If that fails, then mass-struggle becomes imperative. (16)

Marxist philosophy is known for its clamour for revolutionary change. As Marx puts it, "Philosophers have only interpreted the world in various ways, but the point is to change it" (Qtd in Gates 7). According to Onoge, Marxism expresses "the politics of oppression versus the politics of liberation" (4). It advances the idea of the inevitability of revolutionary change that is provoked by the oppressed against oppression and acts of dehumanisation on the part of the oppressors. In order that Marx's ideology of social change favouring the oppressed and victimised class of the society could come to fruition in If: A Tragedy of the Ruled, the tenants use the weapon of solidarity to fight all forms of exploitation. This is asserted through Hamidu:

Solidarity. The day our solidarity dissolves is the day our humanity ends and our worthlessness begins... Nobody should be deemed useless in a struggle against oppression. Not even our classified brother here - Garuba. The same goes for Betty. And you Chinwe and me, and all of us. Nobody is useless. (16-17)

The dehumanising impact of the capitalist system is felt most through the characters of Garuba and the fisherman. Garuba Kazaure is a victim of capitalism who earns a living by boxing at night and carrying cement during the daytime, until the day when he kills his opponent. As revealed by Hamidu,

...That was the end of his dream, his hopes, his humanity. Henceforth, he withdrew from boxing, withdrew from life himself, shutting himself up in what in medicine we call hysteria neurosis. How about that? A once healthy and normal man simply stopped talking, stopped hearing. It is the system. The notoriously impelling capitalist system had driven him to a career he basically hadn't the heart for ... Now a new man. The way the system prefers him to be - a new man totally dehumanized. A man no more a man but: a THING! (17)

The fisherman is also a victim of the capitalist system. The rigs put in the riverine areas by oil companies have affected fishing activities and have ultimately created economic hardship in the society. As Mama Rosa puts it,

Fisherman dem no get anytin again. Fish for sell no dey; fish to eat self, no dey. So so black oil full up for river, dey look dem for face. (26)

Without any provision for a solution either from the side of the government or from the Oil Company, the fisherman is arrested for not paying tax. The result 
of the elections and the death of Onyema (the hope of the society) bring a tragic mood to the play. The people's hope that change will come out of the forthcoming election is dashed as the election takes place and the Landlord's party wins. Both old and young are deceived by the false grandiose concept of a triumph at the polls which will lead to a greater future for Nigeria.

What is more tragic in If: A Tragedy of the Ruled is the gap between what the reality is in the society and what is ideal. It is this gap that the proletariat should endeavour to bridge. Onyema is the embodiment of the future. This future would have been glorious if the masses had won through electoral politics. But the masses lose, thereby failing to bring about change through electoral politics. What is more, they destroy Onyema's hope of a brilliant future and Onyema himself. Worst of all is the arrest and brutal manhandling of Garuba and Betty before Onyema's very eyes. In the words of Banji:

The arrest and brutal manhandling of the common man proved too revolting for his young mind to bear. He must have asked himself one question: does a boy like him, honest and sensitive - does he stand a chance in a nation with no value for the dignity of man? A nation where money and position mean everything? What is the future of our children? Indeed, where is the future of Africa herself? (80)

Rotimi seems to be saying that with the failure of the masses to effect change through the ballot box, there is no other alternative than death, as in the case of Onyema; or individual self-preservation as in the case of Papa, who loses faith and hope in the future. Rotimi chooses electoral politics as one of the ways of changing our society. He believes that violence becomes an alternative when electoral politics fails. This is so because no oppressor will willingly relinquish power unless he is forced to do so.

If: A Tragedy of the Ruled is an experimental play which has many faults. For example, it lacks the aesthetic balance between craft and content enjoyed by other tragedies written by Rotimi. There is lopsided characterisation and disoriented plotting. Using the words of Johnson:

The playwright appears to have got carried away by the social and economic tensions in Nigerian society. The ideological didactic humanistic aspects and the traditional elements especially the songs are poorly assimilated into the drama. (Johnson 1982: 153)

This poor assimilation could be traced to the playwright's first amateurish attempts at using Marxist ideology as a way to reveal the oppression of the poor masses that seek freedom from all economic, political and social forms of oppression. However, the shortcomings, recorded in If: A Tragedy of the Ruled, are adequately taken care of in Hopes of the Living Dead. 


\section{Hopes of the Living Dead}

In Hopes of the Living Dead, Rotimi's Marxist vision is built on historical facts. In this play, Rotimi mirrors the historical events of the life of a Kalabari man called Ikoli Harcourt Whyte together with his fellow lepers. Harcourt Whyte was one of the forty lepers who were hospitalised in Port Harcourt General Hospital for an experiment on a cure for leprosy. A Scottish Medical Practitioner, Dr. Fergusson, undertook the medical research in 1924. However, Dr. Fergusson was soon nicknamed "the mad Scotsman" as a result of public criticism of his experiment in a "normal" hospital. Discouraged, Dr. Fergusson returned to Scotland, leaving the patients at the mercy of the British Colonial Administration. The public complained bitterly against the British Colonial Administration for harbouring the lepers in the midst of people instead of sending them into the bush.

The lepers feel dehumanised. After all, they too are human beings and have their right to existence. Forgetting their differences and weaknesses, they come together in solidarity under the indefatigable and selfless Harcourt Whyte to struggle against their inhuman treatment. Harcourt Whyte takes on himself the mantle of leadership. He makes the lepers believe that their success is dependent on a collective struggle rather than on an individualistic one. On this, he says:

From now, we are alone... we fool ourselves if we believe that the big man of this place will care for us as before. We fool ourselves if we think the world outside will give us peace to continue to be as one blood, together, in this place. Children of our fathers, our struggle has begun. (17)

Rotimi has shown us through the characters of the lepers that the grievances of the masses cannot be thrown aside just because they are physically disabled. In other words, man should be considered on the basis of humanity, and not necessarily because of his position or the class he belongs to. The lepers plead to be treated as human beings.

Give us a chance to live like human beings or we shall remain bones in your selfish throats forever... A place we can call our own, where we can keep ourselves, feed ourselves, work for ourselves... Give us a chance, and leave the rest to our glory or our shame. That is all we ask. $(35-37)$

The oppressors, however, consider the plea as a dream which can never become a reality because no oppressor will willingly set free his or her subjects. The Police Superintendent, who represents the oppressors, echoes thus:

I see. But have you weighed the economic implications of that dream? My dear fellows, the land of Canaan in modern times doesn't flow with milk, I dare say. It doesn't give off honey, either. It takes money. Cash. And where do you propose to get that? Not from the government I suppose. Good intentions aside, no government ever budgets for dreams of Canaan land these days. (35) 
The play presents lepers who revolt against the repressive colonial authority and the Nigerian petit bourgeois, despite the fact that they are physically disabled. Ross Murfin and Sapryia M. Ray explain that Marxist literature aims to "challenge the prevailing social order" (197). The lepers challenge the reigning anti-leper order of the government and fight against the anti-masses order which is in vogue. They fight for the reign of another order that is people-oriented and masses conscious. Consequently, they learn to work collectively to show their determination as reflected in the words of Harcourt Whyte:

We shall wait! And there is no question, ours shall be victory in the struggle to live... Like... free men. Why? Because, try as it might, this world shall never find chains strong enough to tie down freedom! (37)

The lepers refuse to see their disability as an obstacle to getting their freedom. They are optimistic that their struggle will yield them a positive result. They also believe that they need to fight together to bring about their expected freedom; to live like free men. There is no room for individualism, but for collectivism.

Hopes of the Living Dead could be seen as a metaphor of the lepers' revolt of 1928 to show that the lepers' struggle against colonial authority was aimed at re-asserting their humanity. Indeed, Rotimi uses this historical fact to conscientise contemporary Nigerian society that if disabled lepers could forge unity among themselves and live harmoniously, why can't we, able-bodied Nigerians, advance to a better Nigeria with our self-government. It is high time we struggled collectively for a truly democratic society. By extension, for any meaningful progress to be made, the downtrodden must be consciously awakened to the concrete realities surrounding their situation. They must see themselves as the very equals of their oppressors and demand their rights.

\section{A comparative analysis}

A careful study of Rotimi's If: A Tragedy of the Ruled and Hopes of the Living Dead has revealed that the themes of the plays are based on revolution, informed by Marxist Materialist thought and insight. The two plays demonstrate Marxist aesthetics which agitate for social change. This is in consonance with Carol and Henderson's position that "... in true Marxism, both criticism and performance have social change as its primary goal" (309). The conflicts in the works are situated between groups in the society, rather than in the realm of metaphysics. The revolutionary forces in the plays are essentially located among the oppressed groups against the oppressors. In If: A Tragedy of the Ruled, the forces are located among the tenants against the Landlord, while in Hopes of the Living Dead, the forces are from the lepers against the government.

Marxist aesthetics sees a huge gulf between the two groups: the poor, also called the proletariat, and the ruling class, also known as the bourgeoisie, those 
who own the means of production. Ross Murfin and Sapryia M. Ray contend that Marxist aesthetics deal with literary works that "emphasize the role of class and ideology" (197). Marxist aesthetics show that the ruling class not only owns the means of production, such as money, but also controls the political power. It then reveals that power belongs to the masses and must in the long run be seized by the masses through the use of force. Hence, the relationship between the two is characterised by struggle, conflict and tension. The final winner, of course, is, and always will be, according to this Marxist aesthetic, the proletariat. The Marxist aesthetics portrayed in the plays under consideration deal with themes which are centred on man's freedom achieved through struggles rather than through any metaphysical forces.

In Hopes of the Living Dead, in spite of the hardship that one finds within the lepers' domain, the play ends on an optimistic note, as the lepers' request is granted by the government. Hence, the revolution, which is a failure in If: A Tragedy of the Ruled, becomes a success in Hopes of the Living Dead. The creation of socialism, which is a dream in If: A Tragedy of the Ruled, becomes a reality in Hopes of the Living Dead. This is in support of Amuta's assertion that Marxist aesthetics engage "the progressive nature of proletarian art" (505).

Rotimi's concept of heroism in his early plays is tailored along Aristotelian lines. His treatment of the common people reveals that they are nothing. According to Aristotle, neither a woman nor a slave can become a hero because while the former is inferior, the latter is worthless. Mildred Mortimer's idea of "a double dialectic: the individual hero versus the collective hero" (546) becomes useful at this juncture. The notion of individual heroism is applicable to Rotimi's early plays in which an individual hero fights for his own selfish interests and wins the battle alone. However, Rotimi breaks new grounds in If: A Tragedy of the Ruled and Hopes of the Living Dead by presenting tragedy through the eyes of the commoners. The two plays do not follow the Aristotelian conception of the tragic mode. He makes use of ordinary citizens as protagonists. The plays are revolutionary and more didactic. This shows that the popular idea of tragedy as laid down by Aristotle in his Poetics is inadequate in describing all areas of tragedy. As Brian Crow puts it:

...Any definition of tragedy, which seeks to be universally applicable is likely to be unacceptable because it does not take into account the changing social and historical aspects of tragic experience. (Crow 1983: 127)

The playwright debunks the Aristotelian myth that nothing can be satisfyingly tragic about the life of the ordinary citizen in society. Here, the ordinary citizen, who is faceless in his early tragedies, becomes important in his later tragedies. The notion of collective heroism is also applied in the plays under consideration . For example, in Hopes of the Living Dead, Harcourt Whyte refuses to be an individual hero. He refuses to be treated differently from the other lepers. Thus, Harcourt Whyte and his fellow lepers fight and win the battle together. They are the collective heroes of the proletariat's conquest. 
Rotimi also makes a radical departure from his Aristotelian concept of feminism as portrayed in his early tragedies. His treatment of women in the later tragedies is anti-Aristotelian. For example, in Hopes of the Living Dead, Hannah is portrayed as being positive and progressive. She is portrayed more positively than Rotimi's other female characters in the early tragedies. She represents every female in Nigeria in order to reveal that females too can reason critically and be up and doing like their male counterparts. ${ }^{9}$

In the area of language, Rotimi is more down to earth. For instance, in If: $A$ Tragedy of the Ruled, all but Hamidu and Banji, who speak in refined elevated language as spokesmen for Marxists, speak in their mother tongues or in Pidgin English. In Hopes of the Living Dead, there are at least eight different Nigerian languages which are used to pass across the same decision at the same time to the inmates through "each one tells one" phraseology. ${ }^{10}$ This communicative device is called ultra-realism, a conscious effort aimed at reaching a wider cross-section of Nigerians who might be deficient in the English Language and whose consciousness must be re-awakened for the anticipated revolution. It is also used by the playwright to stress the importance of unity in diversity.

Ola Rotimi combines Yoruba dramatic aesthetics ${ }^{11}$ with that of Marxism in the plays under consideration to emphasise the urgent need for "collective struggle", "self-reliance" and "purposeful leadership" for national solidarity by unveiling the suffering, aspirations, frustrations, feelings and deprivation of the ordinary people. Rotimi's significance in these plays lies more in his humanistic concern, dedicating the dramas to the struggle for a truly democratic form of government in our society. (Gbilekaa 1997: 157)

\section{Conclusion}

This analytical study of Rotimi's If: A Tragedy of the Ruled and Hope of the Living Dead has shown that Rotimi moves away from presenting tragedy through the eyes of noble people to presenting it through the eyes of the proletariat. Emphasis is shifted from nobility to "commonness" to demythologise the myriad of bourgeois myths for pedagogical purposes. The plays are in line with Marxist drama whose main goals include political conscientisation and mobilisation for the purposes of praxis. This pedagogical imperative of the dramatic and theatrical arts within the

${ }^{9}$ Aristotle, in his "Poetics", argued that a woman is an inferior being and therefore valour or unscrupulous cleverness portrayed in her character is inappropriate.

10 "Each one tell one" phraseology is a communicative technique of using many interpreters to interpret in local languages at the same time to people who are deficient in the English Language, telling them what has been said by an English speaker.

11 This refers to the Yoruba belief in collectivism. Any Yoruba person who practises individualism is looked down upon as being foreign to his culture. 
framework of Marxist aesthetics for progressive purposes has long been advocated by Bakary Traore:

A strong mobilization of African peasant people by a rural education whose success will be assumed by breaking down traditional family structures and freeing the peasants from the weight of customs, can be achieved through the theatre. ...Is it not time to use the theatre, this pre-eminently popular art form, to break down traditions, which constitute an impediment to progress? (Traore 1972: 116)

One, however, agrees with Osofisan's observation that:

...The real struggle, the real truth is out there among you, on the street, in your homes, in your daily living and dying...12

The theatre is a "fictional world" where societal problems are discussed with the aim of conscientising the audience to work towards their resolution. And since these problems exist in the society, they have "to be solved in the society" (Richard 1987: 282).

Thus, we can conclude that Rotimi wrote If: A Tragedy of the Ruled and Hopes of the Living Dead with a conscious aim of not only reflecting the society as it is, but also with the aim of presenting the society as it ought to be. He brings to the fore the philosophy that "not to do something is to be crippled fast... to lie down resigned to fate is madness." "13 ACTION among the proletariat is the magic word, which works only through solidarity. This is in agreement with "Marx's philosophy" as revealed by Carol and Henderson, which "is grounded in a notion of action rather than analysis or reflection" (309).

\section{References}

Adelugba, D. 1984. "Adelugba in an Interview with Ola Rotimi." Literature, the Arts, Culture and Education 1:3.

Amuta, Ch. 2007. "Marxist Aesthetics: An Open-Ended Legacy.” In: Olaniyan, T. and A. Quayson (eds.). African Literature: An Anthology of Criticism and Theory. Malden: Blackwell Publishing Ltd.

Aristotle, 1974. "Poetics." In: Dukore, B.F. (ed.) Dramatic Theory and Criticism: Greeks to Growtowski. New York: Holt, Rinehart and Winston, Inc.

Aristotle's Poetics 1961. Butcher S. (trans.). New York: Hill and Wang.

Balewa, S. 1982. "Kurunmi: A Drama of the Ruling Class." A seminar paper presented at a Staff Seminar, Ahmadu Bello University, Zaria.

Carol, S.S. and B. Henderson 1993. Performance: Texts and Contexts. White Plains: Longman Publishing Group.

Ceasaire, A. 1970. "The Responsibility of the Artist." In: Wilfred, C. and M. Wilson (eds.). The African Leader. New York: Vintage Books.

Crow, B. 1983. Studying Drama. Ibadan: Longman.

Gates, L.H. 1992. Loose Canon. New York: Oxford University Press.

12 The Director's concluding remarks in Femi Osofisan's Morountodun and Other Plays, 1982: 79.

13 The Narrator in Ola Rotimi's The Gods Are Not To Blame, 1979: 6. 
Gbilekaa, S. 1997. "Romance with the Left: Ola Rotimi's New Artistic Vision.” In: Saint Gbilekaa (ed.). Radical Theatre in Nigeria. Nigeria: Calitop Publications Limited.

Jeyifo, B. 1984. "The Hidden Class War in the Road." Ife Monograph on Literature and Criticism.

Johnson, A.C. 1982. “Ola Rotimi: How Significant?.” In: Jones, E.D. (ed.). African Literature Today 12.

Miller, A. 1974. "Tragedy and the Common Man." In: Dukore, B.F. (ed.). Dramatic Theory and Criticisms: Greeks to Grotowski. New York: Holt Rinehalt and Winston, Inc.

Mortimer, M. 2004. "African Literature in French: Sub-Saharan Africa during the Colonial Period." In: Abiola, I. and S. Gikandi (eds.). The Cambridge History of African and Caribbean Literature. Vol. 2. Cambridge: Cambridge University Press.

Murfin, R. and S.M. Ray 1998. The Bedford Glossary of Critical and Literary Terms. London: Macmillan Press Ltd.

Obafemi, O. 1988. "Society and the Ideological Content of Drama in Nigeria." Work in Progress 6.

Onoge, Omafume 1984. "Toward a Marxist Sociology of African Literature.” In: Ogunba, O. (ed.). Ife Studies in African Literature and the Arts. Ile-Ife: Department of Literature in English, University of Ife.

Osofisan, F. 1982. Morontodun and Other Plays. Ikeja: Longman Nigeria Ltd.

Osundare, N. 1980. "Social Message of a Nigerian Dramatist." West African Magazine. no 3262.

Richards, S.L. 1987. "Towards a Populist Nigerian Theatre: The Plays of Femi Osofisan." New Theatre Quarterly 3.

Rotimi, O. 1971. Kurunmi. London: Oxford University Press.

-. 1974. Ovonramwen Nogbaisi. Ibadan: University Press Limited.

—. 1979. The Gods Are Not To Blame. Ibadan: University Press Limited.

-. 1983. If: A Tragedy of the Ruled. Ibadan: HEB.

—. 1988. Hopes of the Living Dead. Ibadan: Spectrum Books Limited.

Traore, B. 1972. The Black African Theatre and its Social Functions. Adelugba, D. (trans.). Ibadan: Ibadan University Press.

Tse-Tung, M. 1967. "Talks at the Yenan Forum on Literature and Art.” In: Tse-Tung, M. (ed.) Literature and Art. Pekin: Foreign Language Press. 